FOLIA

HORTICULTURAE

Ann. 20/2, 2008, 103-110

DOI: 10.2478/fhort-2013-0119

\title{
The effect of bio-preparations on the infestation of tubers by Streptomyces spp.
}

\author{
Halina Kurzawińska, Stanisław Mazur \\ Department of Plant Protection \\ Faculty of Horticulture, University of Agriculture in Kraków \\ 29 Listopada 54, 31-425 Kraków, Poland \\ e-mail: hkurzaw@ogr.ar.krakow.pl,smazur@ogr.ar.krakow.pl
}

Key words: potato, common scab, chitosan, Pythium oligandrum

\begin{abstract}
The effect of tuber dressing and plant spraying with Polyversum (B.A.S. Pythium oligandrum) and Biochikol 020 PC (B.A.S. chitosan) bio-preparations on the infestation of potatoe tubers by Streptomyces spp. was studied during the 2005-2007 years. The Vitavax 2000 FS (B.A.S. karboxin and thiuram) was used as a standard fungicide.

The results received from field experiments indicate that, during all years of study these preparations significantly reduced tubers infestation by Streptomyces spp. The Polyversum bio-preparation, which was applied to tuber dressing and sprayed on plants four times during vegetation period, showed the best protective effect against Streptomyces spp.
\end{abstract}




\section{INTRODUCTION}

Common scab (Streptomyces spp.) is one of the most frequently occurring diseases on the potatoes tubers peel. Harmfulness of disease in question lies in market value reduction of eatable potatoes, decreasing the quality of raw material supplied for processing industry and seed value of tubers (Gawińska-Urbanowicz 2000). Streptomyces scabies, S. acidiscabies, S. aureofaciens and S. caviscabies belongs to main species which cause scab's symptoms on potatoes (Valkonen 1998). Three new species: S. europeanscabies, S. stellascabies and $S$. reticuloscabies were isolated not long ago in France by Bouchek-Mechiche et al. (1999). Common scab of potato may appear on various organs of this plant: on tubers, stolons and roots. The most common and as well as the most inconvenient form of discussed disease is scab occurring on tubers peel. On peel scab causes irregular, brown scabs separated from healthy tissue by the layer of suberized cells. The inoculum of bacteria which colonize the soil and bacteria appearing on the affected tubers are the source of infection. According to Brazda $(1994,1995)$ pathogen brought into question occurs with particular intensification on light, dry and warm sands, with the soil solution of neutral or alkaline reaction. Moreover, Brazda claims that such forecrops as: tomato, sugar-beet, cabbage, rape, pea, bean, poppy and maize have an influence on stronger tubers infestation by common scab. Scholte (1989), Głuska and Nowacki (2001) suggested that all cultivars are subjected to the infestation, but their immunity is different. Numerous authors believe that important effect on tubers' infestation by Streptomyces spp. has soil and climatic conditions, and especially precipitation during the tubers formation period (Davis et al. 1974, Rudkiewicz and Zakrzewska 1987, Głuska and Nowacki 2001, Kurzawińska and Gajda 2004).

Among various methods, in protection of plants against diseases, the biological method constitute nowadays an important share. Mentioned biological method among means uses special microorganisms which are characterized by a strong antagonistic reaction towards specific pathogens. The micoparasitic Pythium oligandrum which is the biologically active substance of Polyversum biopreparation belongs to discussed antagonistic microorganisms (Kurzawińska 2008). Moreover there are high possibilities of chitosan application in plants protection against diseases (including potatoes). According to Pośpieszny (1997), Kurzawińska and Mazur (2007), Biochikol 020 PC preparation induces immunity of many plants through cell walls lignification, phytoalexins production and synthesis of proteinase inhibitors.

The purpose of three years study was to assess the effect of tuber dressing and plant spraying with Polyversum bio-preparation and Biochikol 020 PC preparation on tubers infestation by Streptomyces spp. during the vegetation period. 


\section{MATERIAL AND METHODS}

The field experiment was conducted at the Experimental Station at Mydlniki near Kraków during the years 2005 - 2007 (station belongs to the Department of Plant Protection University of Agriculture in Kraków). The experiment was started on the sandy dust type of soil with the $6.1 \mathrm{pH}$. The winter wheat was the forecrop. Potatoes of mid-early 'Ibis' cultivar was used during the study period. Soil management, cultivation and fertilization were carried out according to recommendation of proper agrotechnique. The state of tuber health with regard to infestation by Streptomyces spp. was assessed directly after harvest. The share of diseased tubers in samples and the mean infestation degree were determined and noted down (100 tubers from each plot).

The experiment was begun in third decade of April using the method of random squares in four replications (100 tubers on each plot) and in the following combinations: 1 - control - plants derived from tubers without any protection treatment; 2 - plants derived from tubers dressed with Biochikol 020 PC (B.A.S. chitosan) at a concentration of $2.5 \% ; 3$ - dressed tubers + plants sprayed four times with Biochikol $020 \mathrm{PC}$ at a concentration of $2.5 \%$; 4 - plants derived from tubers dressed with Polyversum (B.A.S. Pythium oligandrum) in a dose $10 \mathrm{~g} \mathrm{~kg}^{-1}$ tubers; 5 - dressed tubers + plants sprayed four times with Polyversum at a concentration of $0.05 \% ; 6$ - plants derived from tubers dressed with Vitavax 2000 FS (B.A.S. karboxin and thiuram) in a dose $5 \mathrm{ml} \mathrm{kg}^{-1}$ tubers.

After harvesting 100 tubers from each plot were randomly chosen. The analysis of tuber infestation by Streptomyces spp. was made directly after harvest. Both the share of affected tubers in the sample and the mean degree of infestation by aforementioned pathogens were defined on the base of a 1-9 scale, where $1=$ the least infestation and $9=$ very strong infestation (Roztropowicz 1985). The results were subjected to statistical analysis using analysis of variance. The multiple range t-Duncan test was used for estimating the differences between mean values at significance level $\mathrm{p}=0.05$.

Figures 1 and 2 demonstrate the meteorological conditions during the vegetation period in the three years of study $(2005-2007)$. In the south region of Poland the spring in 2005 season and as well 2006 year was relatively cold. Mean temperatures in May were respectively $13.2^{\circ} \mathrm{C}$ and $13.6^{\circ} \mathrm{C}$. Spring in 2007 year (with the exception of the first decade of May) was slightly warmer and mean temperature in May was $15.4^{\circ} \mathrm{C}$ (Fig. 1). The precipitation schedule was very variable during vegetation period in 2005 - 2007 years. From May to July in 2005 year the sum of rainfall was $247 \mathrm{~mm}$ and in 2007 year 183 respectively. However in 2006 year the sum of rainfall was the lowest and in analogous period of this year amounted $151 \mathrm{~mm}$. The lowest rainfall was noted in July 2006 year $-25 \mathrm{~mm}$ (Fig. 2). 


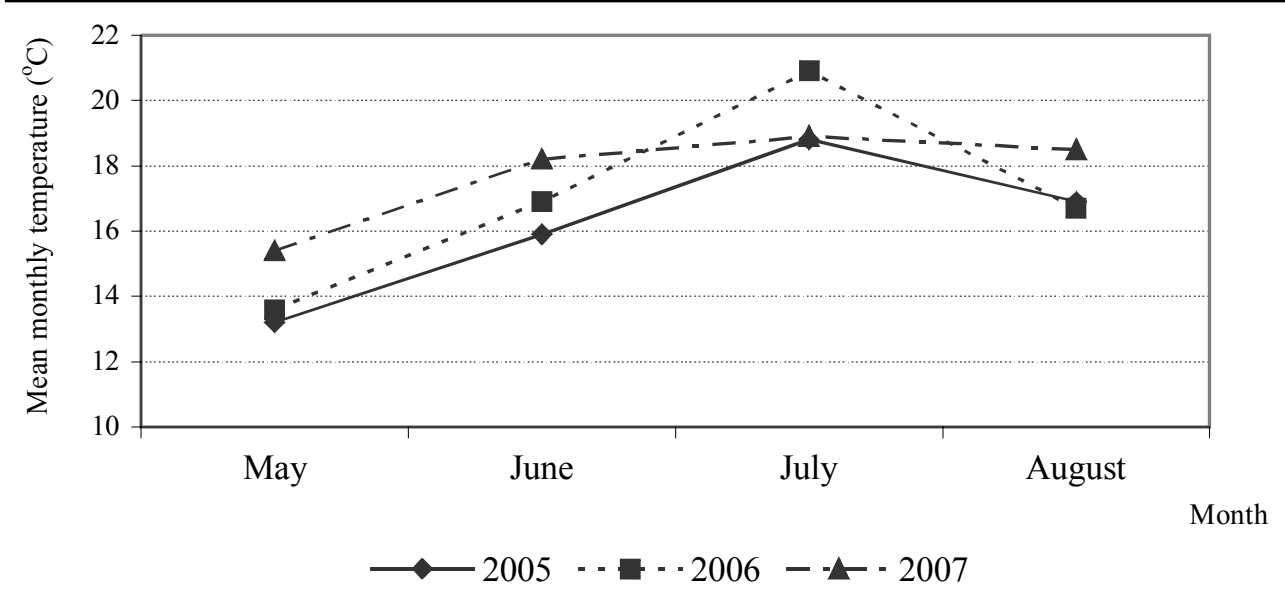

Fig. 1. Temperature schedule during the vegetation season 2005-2007

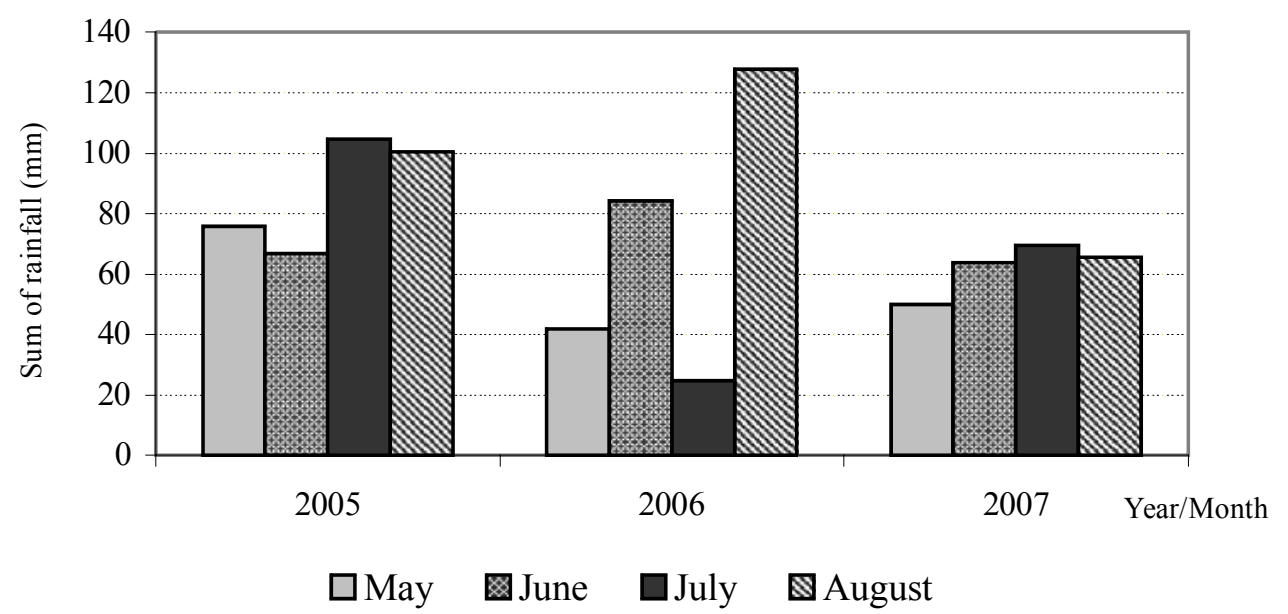

Fig. 2. The sum of rainfall during the vegetation season 2005-2007

\section{RESULTS AND DISCUSSION}

The results obtained from analysis during three years of study indicate that both mean degree of infestation and share of seed-tubers infected by Streptomyces spp. were relatively low and came to $1.8-2.3$ and $6.0-8.6 \%$ respectively (Table 1 ). 
Table 1. Estimation of seed-tuber health with regard of infestation by Streptomyces spp.

\begin{tabular}{lcccc}
\hline \multirow{2}{*}{ Feature } & \multicolumn{3}{c}{ Years } & \multirow{2}{*}{ Mean } \\
\cline { 2 - 4 } & 2005 & 2006 & 2007 & \\
\hline Percent of infested tubers & 6.0 & 8.2 & 8.6 & 7.6 \\
\hline Degree of infection at 1-9 scale & 1.8 & 2.0 & 2.3 & 2.0 \\
\hline
\end{tabular}

The tuber infestation value by Streptomyces spp. was diversified during 3 year of the study. In the first year of analysis the highest tubers' infestation by Streptomyces spp. was observed in control combination (24.3), and the lowest in combination where tubers were dressed and plants were four times sprayed with Polyversum bio-preparation (15.0). Mean infestation degree of tubers amounted to 2.6 and 1.9 respectively (Table 2). During the second year of investigation study the increase of proportional tubers' infestation by Streptomyces spp. was noted in control combination (26.4) - Table 2 . It seems to have relationship to relatively lowest sum of rainfall during the May - July in 2006 year (Fig. 2). In that particular year Vitavax was the most effective against infection by Streptomyces $11 \%$ of analysed tubers were infested. As suggested by Grześkiewicz et al. (1990), intensification of common scabs' symptoms is observed during dry seasons. In the third year of study the decrease of infestation by Streptomyces spp. was observed in the control combinations $-22.6 \%$. The lowest share of tubers with common scab symptoms was observed in combination, where potatoes were dressed and plants were four times sprayed with Polyversum bio-preparation (12.3) - Table 2.

Table 2. The effect of tested preparations on potato tubers infestation by Streptomyces scabies

\begin{tabular}{|c|c|c|c|c|c|c|c|c|}
\hline \multirow{3}{*}{ Combination } & \multicolumn{4}{|c|}{ Percent of infested tubers } & \multicolumn{4}{|c|}{$\begin{array}{c}\text { Mean degree of infestation } \\
\text { at } 1-9 \text { scale }\end{array}$} \\
\hline & \multicolumn{3}{|c|}{ Years } & \multirow[t]{2}{*}{ Mean } & \multicolumn{3}{|c|}{ Years } & \multirow[t]{2}{*}{ Mean } \\
\hline & 2005 & 2006 & 2007 & & 2005 & 2006 & 2007 & \\
\hline Control & $24.3 \mathrm{c}^{*}$ & $26.4 \mathrm{~d}$ & $22.6 \mathrm{~d}$ & $24.4 \mathrm{e}$ & $2.6 \mathrm{c}$ & $2.5 \mathrm{c}$ & $2.6 \mathrm{c}$ & $2.6 \mathrm{c}$ \\
\hline $\begin{array}{l}\text { Tubers dressed - } \\
\text { Biochikol 020 PC }\end{array}$ & $18.0 \mathrm{~b}$ & $17.9 \mathrm{c}$ & $14.6 \mathrm{bc}$ & $16.8 \mathrm{~d}$ & $2.2 \mathrm{~b}$ & $2.0 \mathrm{~b}$ & $1.9 \mathrm{~b}$ & $2.1 \mathrm{~b}$ \\
\hline $\begin{array}{l}\text { Tubers dressed } \\
\text { and plants sprayed - } \\
\text { Biochikol 020 PC }\end{array}$ & $16.5 \mathrm{ab}$ & $15.3 \mathrm{bc}$ & $13.1 \mathrm{ab}$ & $15.0 \mathrm{bc}$ & $2.0 \mathrm{ab}$ & $1.8 \mathrm{a}$ & $1.6 \mathrm{a}$ & $1.8 \mathrm{a}$ \\
\hline $\begin{array}{l}\text { Tubers dressed - } \\
\text { Polyversum }\end{array}$ & $18.3 \mathrm{~b}$ & $14.6 \mathrm{~b}$ & $15.3 \mathrm{c}$ & $16.1 \mathrm{~cd}$ & $2.0 \mathrm{ab}$ & $2.0 \mathrm{~b}$ & $2.0 \mathrm{~b}$ & $2.0 \mathrm{~b}$ \\
\hline $\begin{array}{l}\text { Tubers dressed } \\
\text { and plants sprayed - } \\
\text { Polyversum }\end{array}$ & $15.0 \mathrm{a}$ & $12.6 \mathrm{ab}$ & $12.3 \mathrm{a}$ & $13.3 \mathrm{a}$ & $1.9 \mathrm{a}$ & $1.8 \mathrm{a}$ & $1.8 \mathrm{~b}$ & $1.9 \mathrm{a}$ \\
\hline $\begin{array}{l}\text { Tubers dressed - } \\
\text { Vitavax } 2000 \mathrm{FS}\end{array}$ & $15.9 \mathrm{a}$ & $11.1 \mathrm{a}$ & $14.4 \mathrm{bc}$ & $13.8 \mathrm{ab}$ & $2.2 \mathrm{~b}$ & $2.0 \mathrm{~b}$ & $1.9 \mathrm{~b}$ & $2.0 \mathrm{~b}$ \\
\hline
\end{tabular}

*values followed by the same letter within column do not significantly differ at $\mathrm{p}=0.05$ (Duncan's multiple range test) 
Results obtained from three years of field experiments indicate favourable effect of tubers dressing and as well as plant sprayed four times with tested preparations on the inhibition of descendant tubers infestation by Streptomyces spp. (Table 2). Statistical analysis indicate that throughout the experimental period both share of infected tubers and mean infestation degree by Streptomyces spp. were significantly lower in comparison to the control in combination where the application of biological and chemical preparations were in action. Similar results were obtained by the co-author in previous research work (Kurzawińska 2002). Kurzawińska (1992), Kurzawińska and Gajda (2004) also demonstrated the interaction between large quantity of Streptomyces spp. inoculum on the tubers and higher infestation of descendent tubers. Forementioned authors observed also that meteorological conditions in particular years of study significantly modified the share and infestation degree of tubers by Streptomyces spp. A considerable increase of common scab symptoms was observed in the year 1999, which was characterized by the very dry summer.

Among biological preparations taken under consideration the Polyversum preparation applied as tubers dressing and plants spraying demonstrated the best protective effect. The mean percent of affected tubers came to 13.3 and the mean infestation degree was on the average of 1.9 (Table 2) during three years of study. Similar reaction was observed in combination where Vitavax 2000 FS and Biochikol 020 PC was used to tubers dressing and plants spray program. Strong chitosan efficiency in potato protection against infection by peel pathogens was also confirmed in earlier study conducted by Kurzawińska and Mazur (2007). There is an opportunity for further application of the considered preparations in ecological potato production.

Application of biological preparations make possible to eliminate or reduce chemical protection agents, improvement of raw material quality, especially used for ecological food production, environment protection through less interactions of mentioned agents and easier biodegradation in the environment.

\section{CONCLUSIONS}

1. All applied preparations significantly reduced share and degree of tuber infestation by Streptomyces spp. (in comparison with control).

2. The best protective effect was observed in combinations where Polyversum and Biochikol 020 PC bio-preparations, applied to tuber dressing and sprayed on the plants four times.

3. Obtained results indicate that studied bio-preparations could be useful against Streptomyces spp. in ecological potato production. 


\section{AKNOWLEDGEMENTS}

The studies were financed by The Ministry of Science and Information within grant No PO6 R00129.

\section{REFERENCES}

BoucheK-Mechiche K., GARDAn L., Norman P., JouAn B., 1999. Streptomyces species isolated from potato scabs: description of new species on the basis of phenotypic and genotypic data. Abstr. $14^{\text {th }}$ EAPR Conf., Sorrento: 253-254.

BRAZDA G., 1994. Auftreten des Kartoffelschorfs (Streptomyces scabies) und Möglichkeiten der Berfallsminderung. Kartoffelbau 45(3): 98-105.

BRAZDA G., 1995. Kartoffelschorf (Streptomyces scabies). Besonderheiten des Befalls und des Auftretens. Kartoffelbau 46(4): 150-152.

Davis J.R., Mc Master G.M., Callihan R.H., GarneK J.G., Mc Dole R.E., 1974. The relationship of irrigation timing and soil treatment to control potato scab. Phytopat. 64, 11, 1: 1404-1410.

GAWIŃSKA-URBANOWICZ H., 2000. Występowanie parcha srebrzystego (Streptomyces sp.) na wybranych odmianach ziemniaka w różnych warunkach środowiska. Roczn. AR Poznań CCCXXI, ser. Ogr. 30: 33-38.

GŁUSKA A., NOwACKI W., 2001. Wpływ opadów i warunków glebowych na porażenie bulw parchem zwykłym (Streptomyces scabies). Mat. Konf. IHAR, Oddział Bonin „Ochrona ziemniaka”, Kołobrzeg: 72-76.

GRZEŚKIEWICZ H., RUDKIEWICZ F., SOĆKO J., 1990. Porażenie bulw ziemniaka parchem zwykłym $w$ zależności od stopnia zakwaszenia i składu mechanicznego gleb, nawożenia magnezem oraz ilości opadów. Biul. Inst. Ziemn. 40: 61-73.

KURZAWIŃSKA H., 1992. Wpływ zróżnicowanego nawożenia azotowego oraz trzech terminów sadzenia ziemniaka na występowanie parcha zwykłego (Streptomyces scabies). Zesz. Nauk. AR Kraków, ser. Ogr. 20: 149-159.

KURZAWIŃSKA H., 2002. Fungicydy stosowane w ochronie ziemniaka przed zarazą a występowanie chorób skórki bulw. Zesz. Nauk. AR Kraków 387(82): 81-82.

KURZAWIŃSKA H., 2008. Metoda biologiczna w integrowanej ochronie roślin warzywnych przed chorobami. E. Cieslik (red.) Monografia Pol. Tow. Techn. Żywn., Wyd. Nauk. PTTŻ: 54-62.

KURZAWIŃSKA H., GAJDA I., 2004. Influence of weather conditions on natural infection of potato tubers by common scab (Streptomyces spp.) in medium early cultivars. Veg. Crops Res. Bull. 60: 81-87. 
KURZAWIŃSKA H., MAZUR S., 2007. The effect of Pythium oligandrum and chitosan used in control of potato against late blight and the occurrence of fungal diseases on tuber peel. Comm. Appl. Biol. Sci 72/4: 967-971.

POŚPIESZNY H., 1997. Niektóre aspekty stosowania chitozanu w ochronie roślin. Prog. Plant Prot. 37(1): 306-309.

ROZTROPOWICZ S., 1985. Metodyka obserwacji i pobierania prób w agrotechnicznych doświadczeniach z ziemniakami. Inst. Ziemn. Bonin: 11-20.

RUDKIEWICZ F., ZAKRZEWSKA B., 1987. Wpływ niektórych elementów pogody na porażenie bulw parchem zwykłym i ocena reakcji odmian na tę chorobę. Biul. Inst. Ziemn. 35: 91-100.

SCHOLTE K., 1989. The effect of nettem scab (Streptomyces spp.) and Verticillium daliae on growth and yield of potato. Potato Res. 32: 65-73.

VALKONEN J., 1998. New pathogenic Streptomyces sp. in potato under Nordic conditions (Finland). Abstr. Conf. Papers. European Association for Potato Research Pathology Section Meeting. Uema, Sweden: 10.

\section{WPŁYW ZAPRAWIANIA SADZENIAKÓW I OPRYSKIWANIA ROŚLIN ZIEMNIAKA PREPARATAMI BIOLOGICZNYMI NA PORAŻENIE BULW PRZEZ STREPTOMYCES SPP.}

Streszczenie: W latach 2005 - 2007 badano wpływ zaprawiania sadzeniaków i czterokrotnego opryskiwania roślin ziemniaka biopreparatem Polyversum (s.a. Pythium oligandrum) i Biochikolem 020 PC (s.a. chitozan) na porażenie bulw przez Streptomyces spp.

Na podstawie uzyskanych wyników z doświadczeń polowych stwierdzono, że we wszystkich latach badań stosowane preparaty w sposób istotny ograniczyły procentowe porażenie bulw przez Streptomyces spp. Spośród preparatów biologicznych najlepsze działanie ochronne wykazał biopreparat Polyversum, zastosowany do zaprawiania sadzeniaków i czterokrotnego opryskiwania roślin w okresie wegetacji. 